\title{
Role of the Family in Children's Remote Learning Experiences during the COVID-19 outbreak: Kazakhstan and Hungary ${ }^{1}$
}

\author{
Assel, Csonka-Stambekova ${ }^{2}$ \\ Teacher Education Department, Eötvös Loránd University
}

The COVID-19 outbreak forced schools around the globe to close. As a result, home became the dominant learning environment and family members became educational providers for students. Research to date demonstrates that families responded differently to the challenges related to remote learning and demonstrated various responses in their new responsible roles. Furthermore, research from the initial phases of COVID-19 shows that families' socio-economic status and educational background are related to children's remote learning experiences. This study seeks to explain and advance our understanding of the participants' remote learning experiences in the early stage of COVID-19 through the analysis of three Kazakhstani and three Hungarian families. The families have different backgrounds, including the language they speak, their residential characteristics, parents' educational attainment, and occupational status. The author conducted semi-structured interviews with parents from Kazakhstan and Hungary via Zoom. Qualitative directed content analysis was employed to analyse the collected data. The results of this study indicate that: a) parents had to become teachers in addition to their primary caregiver roles, thus balancing parenting and home-schooling; b) children's learning opportunities and losses during the COVID-19 outbreak are linked to families' socioeconomic status; and c) some families found it difficult to support their children due to their lack of pedagogical and content knowledge. Therefore, it can be concluded that existing social and educational inequalities in Kazakhstan and Hungary may have long-lasting negative effects on the children who did not experience high levels of parental involvement in their remote education.

Keywords: emergent remote learning, COVID-19 outbreak, parents, home learning

1 Preliminary results of this study were presented at the Hungarian Conference on Educational Research 2021 available at http://hera.org.hu/wp-content/uploads/2021/05/Hucer2021_Abstract.pdf.

2 Assel, Csonka-Stambekova, https://orcid.org/0000-0001-5101-2640

This study has received no funding.

Correspondence to: Assel Csonka-Stambekova, Teacher Education Department, Eötvös

Loránd University

Contact: assel.stambekova@ppk.elte.hu 
This qualitative study aims to obtain insight into the changing reality of parental ${ }^{3}$ involvement in children's learning caused by the global pandemic within the real-life context.

Paraphrasing Dickens (1921), we will remember the infectious disease COVID-19 as "the worst of times". During the pandemic, 7,398 schools in Kazakhstan were closed for a total duration of 41 weeks, affecting 5,060,284 learners (Information and Analytic Centre, 2020). Similarly, on March 16, 2020, 1,791,758 Hungarian learners had to stay home as schools closed (UNESCO, 2020). Unexpectedly, the novel virus disrupted traditional education, forcing families to become educational providers for their children.

For many years, access to quality education has existed in Kazakhstan and Hungary. However, school closures revealed larger societal issues and questions. Access to quality education in both countries is related to the type of school students attend, families' socioeconomic status (SES) and parents' educational attainment, the quality of teaching staff and school infrastructure supporting the $21^{\text {st }}$ century learning (OECD, 2019). With little time to resolve challenges and a rapid transition to emergent remote education (ERE) (Bozkurt \& Sharma, 2020), parents had to enable school learning at home, performing as the primary educational resource for children. Governments expected that families could create supportive learning environments at home. However, Kazakhstan and Hungary did not practice remote online learning prior to COVID-19. Therefore, ERE emphasized the disadvantaged position of some families in these countries, due to lack of access to and/or lack of competencies for participation in remote education.

\section{Previous research on parental involvement in student home/remote learning}

Since the 1960s and 1970s, much of the literature on parental involvement in the USA and Europe has emphasised parental participation as an essential aspect of student academic performance in school (Brooks-Gunn et al., 2000). In this way, policymakers encouraged parents, mainly from the white middleclass, to exhibit certain attitudes and behaviours that could guarantee school success for their children. In connection to existing inequalities in education, some schools used the concept of parental involvement to illustrate their choice of ideal parents (Lareau, 2003). By definition, they excluded lowerclass parents who did not align with the required social, economic, and cultural capital (Bordieu, 1986).

Available empirical research on parental participation studied parental involvement in the traditional learning settings. However, this line of research needs to be further studied. The authors who wrote about the

3 The terms parental involvement and family involvement are used interchangeably in this article. 
challenges experienced by parents in remote learning settings mainly mentioned shortage of internet access (Hollingworth et al., 2011), insufficient interest in using technology (Beckman et al., 2019), insufficient digital self-efficacy (Povey et al., 2016), economic resources (Hohlfeld et al., 2010), and parents becoming a school coach for students studying online (Hasler Waters \& Leong, 2014).

However, the studies exploring parental involvement in children's online education prior to COVID-19 and in virtual learning environments are mainly Western-centric. Thus, they may not be representative of the views of parents from the emerging countries with centralised education systems and those in which, due to the family's high social and cultural capital, children attend private schools to access quality learning resources. In the wake of the pandemic, many families in Kazakhstan and Hungary experienced educational inequality in accessing some learning resources because of the limited or non-available devices in many households and families losing their jobs because of the measures to contain the pandemic. This qualitative study aims to explain and advance our understanding of three Kazakhstani and three Hungarian families coming from unique parental, linguistic and educational backgrounds, and their children's remote learning experiences during the lockdown (March 2020-May 2021). The study employs the digital divide concept, Bourdieu's theory of social and cultural reproduction (1986) and Bronfenbrenner's Ecological Systems Theory (EST) (1979).

\section{Parental involvement in student home/remote learning: Theoretical perspective}

Bourdieu's (1986) theory is fundamental in addressing the fact that social, economic, and cultural capital has become instrumental in understanding the family role in supporting student learning, the educational and digital inequalities of students in Kazakhstan and Hungary. Bourdieu's (1986) emphasis on three types of capital is especially useful to the analysis as it allows us to investigate the way in which educational and digital inequalities are widening among schoolchildren. To this end, Bourdieu's (1986) conceptualisation of the social and cultural capital is generative for grasping how highly educated, skilful and well-off families can mitigate the learning losses of their children during the pandemic. Bourdieu's focus on economic capital (1986) is valuable for understanding how the digital divide in Kazakhstan and Hungary contributes to the inequalities in the digital economy in these societies.

In situating Bronfenbrenner's (1979) EST to the study, it is necessary to explain how families adapted to ERE. Bronfenbrenner's focus on a microsystem and mesosystem in which learning happens allows us to 
understand interaction among these microsystems (e.g. school, family, peers) during the pandemic. Bronfenbrenner's (1979) attention to the chronosystem is important to understand how families supported children during the pandemic when individuals had little to no in-person interaction. Before the transition to ERE, families and children had clear boundaries between home and school/work. With the transition to ERE, the division between the spaces used for living and learning disappeared for both families and children. Therefore, it is necessary to learn and analyse how micro- and meso-systems provided support for families and children during the pandemic.

As Bourdieu's (1986) and Bronfenbrenner's (1979) theories posit, those families who take care of their children's education by embedding practices from home and school enable students to benefit more from home remote learning. Specifically, these students benefit by acquiring a variety of technological skills and self-regulation and by experiencing greater learning advantages as opposed to the children from lower SES backgrounds. Hence, this paper argues that children who come from the families of low socioeconomic and educational background and limited digital literacy background are excluded from home-based remote learning opportunities.

\section{A digital divide}

To better understand the impact of insufficient digital resources, skills and attitudes towards using technologies for various educational purposes by particularly low SES families, it is essential to relate to adverse effects of the digital divide. Scholars conceptualized the digital divide as inequalities in accessing and using updated technologies (DiMaggio \& Hargittai, 2001; van Dijk, 2005). Researchers who studied the digital divide pointed out that the divide was connected to income, gender, age, level of education and geographic location. These scholars argued that families of a higher SES had greater digital skills and used more advanced Web applications for educational or information-seeking purposes (van Deursen \& van Dijk, 2011; Scheerder et al., 2017). The families with low SES, on the other hand, used the technologies for communication and entertainment purposes (van Dijk, 2005).

From a socialization perspective, families impose their social and cultural capital through generations, resulting in the reproducing inequalities expressed in attitudes, competencies and knowledge (Bourdieu, 1984; Putney \& Bengston, 2002). This perspective further impacts students' perceptions of social relationships and educational attainment.

Conceptually, the digital divide contributes to the understanding of existing inequalities in accessing and using technologies. However, Hargittai (2002) adopted a broader perspective and argued that there are two contrasting issues of access and ability within the digital divide. Specifically, some authors 
suggest that the presence or lack of the ability to use the technology adds up to differences in the extent to which they can benefit (Hargittai, 2003; Mossberger et al., 2003; van Dijk, 2005). The discrepancy in the extent of skills to use the Web may intensify digital inequality (DiMaggio et al., 2004). This article explores digital inequalities broadly, namely, in the following areas: a) in the Internet access to various applications; $b$ ) in the learning process, i.e. to what extent children instructed their parents how to use ICT; and c) in the ability of families and children to utilize the Internet to benefit from it.

\section{The study context}

\section{Kazakhstan in the context of COVID-19}

In response to school closures because of the COVID-19 pandemic, the Ministry of Education and Science (MoES) in Kazakhstan empowered schools and teachers to approach the flexible organization of online learning. For instance, the MoES introduced and supported the delivery of learning materials by post to remote areas (Официальный информационный ресурс Премьер-Министра Республики Казахстан, 2020), the TV and radio broadcast 10-minute lessons in both Kazakh and Russian language, the use of social messenger WhatsApp and e-mail for feedback between teachers and school students and the use of local Learning Management Systems (LMS) such as Kundelik, BilimLand and Daryn Online. However, the rapid transition to online learning revealed many challenges related to the lack of IT infrastructure nationally, the quality of video-recorded lessons broadcast on TV (Bokayev et al., 2021) and teaching methods aimed at remembering and understanding (Kovyazina et al., 2020). As a result, some teachers recorded lessons, searched for explanations on YouTube, organized Zoom video calls for further tutoring or explained lesson contents in voice messages via WhatsApp (ibid).

Regarding e-learning policies in Kazakhstan, some scholars argued about the effective use of ICT in education by the national educational community (Nurmukhametov, et al., 2015; Sapargaliyev, 2012). In contrast, in their study on high schools and higher education institutions, Dalayeva (2013) and Ibrayeva et al. (2018) revealed financial, legal, and quality issues of distance learning processes. As scholars get a handle on the issues of policy implementation in e-learning, it is also crucial to pay attention to the collateral consequences of ERE and to the key educational providers of remote learning at home, namely, to parents.

In this unfamiliar situation, Kazakhstani parents struggled with analogous challenges in ERE as parents globally. For instance, available research (Kovyazina et al., 2020) reports on the increased levels of stress in parents working from home, the lack of the Internet access and changes in family's 
daily routine (ibid). Specifically, parents of the home-schooled child(ren) felt frustrated because they had to be involved with ERE from the morning until late evening.

Available, yet fragmentary research on the way Kazakhstani parents adapted to remote learning suggests that families gained more insight into their children's learning than before. Therefore, it is important to develop our understanding of how the roles of families changed in providing and supporting children's access to learning at home as the lockdown expanded. The following section summarizes important facts for Hungary considering the global COVID-19 pandemic.

\section{Hungary in the context of COVID-19}

COVID-19 prompted the Digital Transformation of Education, aimed at the digital development of the society and economy in Hungary (DES, 2016). It was ensured that teachers could access online teaching using the E-Kréta platform. This is an online administrative registry platform for all public schools that has existed since 2016 and has been mandatory to use in all other schools since 2018 (Radó, 2021). While Google, Microsoft, and Facebook applications were very popular among Hungarian teachers, only $27 \%$ of teachers nationally used E-Kréta (ibid, p. 24). In comparison, the government support in facilitating the shift to online learning was poor (Csapó \& Molnár, 2019).

Similar to other countries, the transition to online teaching in Hungary revealed methodological differences among teachers (Radó, 2021), sudden involvement of Hungarian parents as teachers (Ede, 2020) and larger socioeconomic reasons for children dropping out of remote learning, such as the lack of proper space at home, lack of independent study skills and digital divide (i.e. no access to computers or other gadgets for remote learning) (Hermann, 2020; Kende-Messing, 2020).

All of the afore-mentioned raises the question of the way in which the digital divide in families and insufficient technological and pedagogical preparation of teachers for online teaching affect the growing inequality in students who come from the low SES. Thus, the following research question guided the study: How do families live through the shift in traditional boundaries in learning environments?

\section{Method}

This research ${ }^{4}$ is a part of a broader mixed methods case study exploring the families' and English school teachers' roles in supporting student learning

4 Data corpus was presented at the Hungarian Conference on Educational Research 2021, available at http://hera.org.hu/wp-content/uploads/2021/05/Hucer2021_Abstract.pdf. 
and maximizing teacher effectiveness during the pandemic in Kazakhstan and Hungary. Before the data collection, the author had developed a case study protocol that guided the research. Families were recruited through advertizing on the Internet (Merriam \& Tisdell, 2016) and asking friends with wider social networks comprised of the families meeting the research criteria (i.e. the families whose child(ren) studied remotely during March 2020-May 2021) (Figure 1).

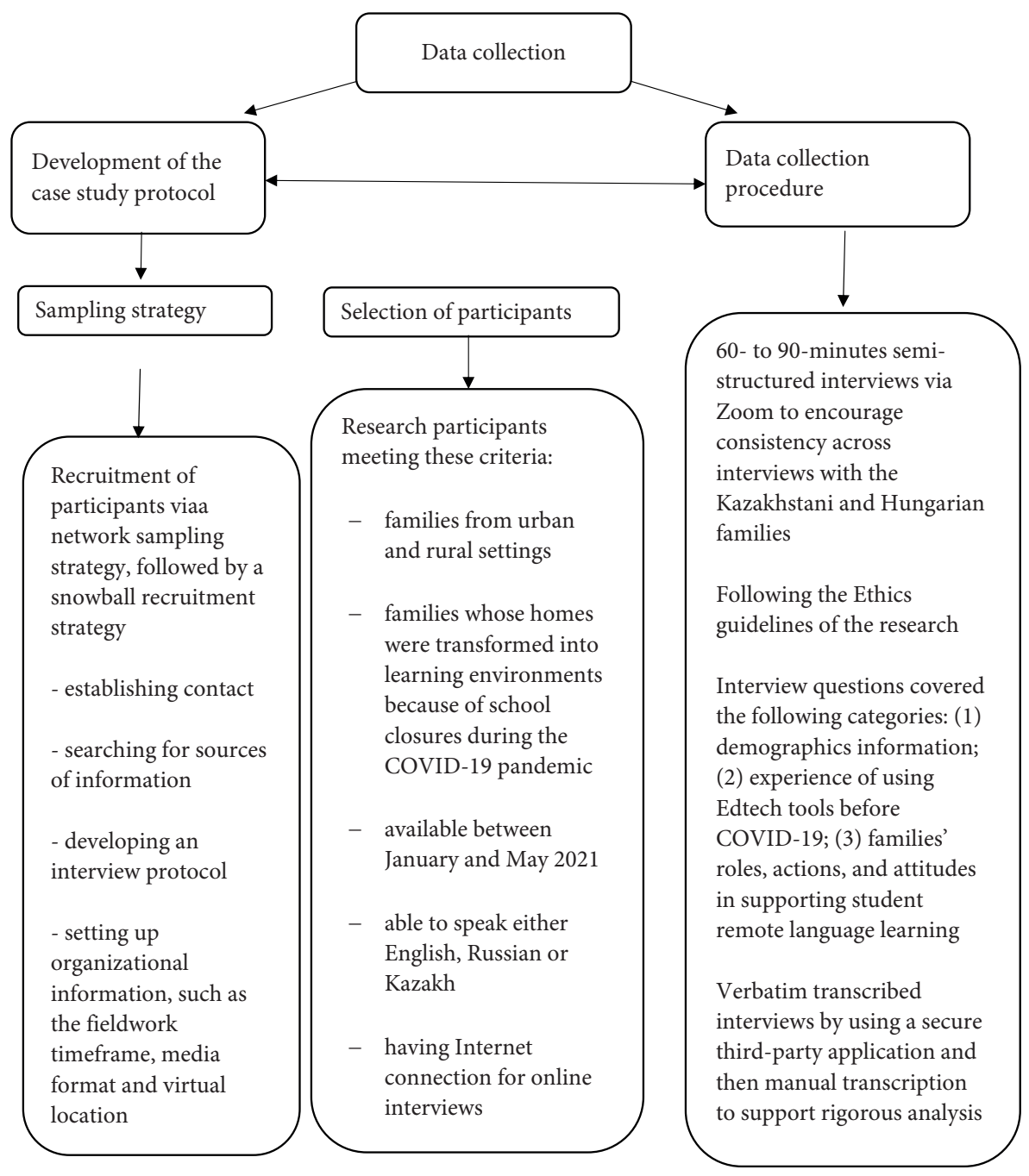

Figure 1. Data collection 
The interviews with parents lasted between 55 and 88 minutes $(M=70$; $S D=19)$ and were conducted in either Russian or English. Parent-participants were male and female from nuclear, extended, single-parent and fostered bilingual and trilingual families, with the majority aged between 45 and 55 (Table 1). All parents had at least a Bachelor's degree. Their children were bilingual, from capital cities in two countries, studying in different types of schools.

Table 1.

Participants' characteristics

\begin{tabular}{|c|c|c|c|c|c|c|c|}
\hline Interviewees & Gender & $\begin{array}{l}\text { Country of } \\
\text { living }\end{array}$ & Age & $\begin{array}{l}\text { Education } \\
\text { level }\end{array}$ & $\begin{array}{l}\text { Languages } \\
\text { spoken in } \\
\text { the family }\end{array}$ & Field of work & Location \\
\hline Family 1 & Female & Kazakhstan & 45 & $\begin{array}{l}\text { Specialist } \\
\text { education }\end{array}$ & $\begin{array}{l}\text { Russian, } \\
\text { Kazakh }\end{array}$ & Finance & $\begin{array}{l}\text { Capital } \\
\text { city }\end{array}$ \\
\hline Family 1 & Male & Kazakhstan & 45 & $\begin{array}{l}\text { Specialist } \\
\text { education }\end{array}$ & $\begin{array}{l}\text { Russian, } \\
\text { Kazakh }\end{array}$ & Health care & $\begin{array}{l}\text { Capital } \\
\text { city }\end{array}$ \\
\hline Family 2 & Female & Kazakhstan & 60 & $\begin{array}{l}\text { Specialist } \\
\text { education }\end{array}$ & $\begin{array}{l}\text { Russian, } \\
\text { Kazakh }\end{array}$ & $\begin{array}{l}\text { Pre-school } \\
\text { education }\end{array}$ & $\begin{array}{l}\text { Capital } \\
\text { city }\end{array}$ \\
\hline Family 3 & Female & Kazakhstan & 35 & BA & $\begin{array}{l}\text { Russian, } \\
\text { English }\end{array}$ & $\begin{array}{l}\text { Primary } \\
\text { education }\end{array}$ & Province \\
\hline Family 1 & Female & Hungary & 55 & MA & $\begin{array}{l}\text { Hungarian, } \\
\text { English }\end{array}$ & Communications & $\begin{array}{l}\text { Capital } \\
\text { city }\end{array}$ \\
\hline Family 2 & Male & Hungary & 40 & BA & Hungarian & E-commerce & $\begin{array}{l}\text { Capital } \\
\text { city }\end{array}$ \\
\hline Family 3 & Female & Hungary & 45 & MA & $\begin{array}{l}\text { Hungarian, } \\
\text { English }\end{array}$ & Health care & Province \\
\hline
\end{tabular}

Participants determined the time for the open-ended interviews, whereas the author offered the virtual location and media format. Since the research took place during the pandemic, participants sometimes felt uncomfortable and anxious to talk about their remote learning experiences. Participants were free not to speak about uncomfortable or anxious topics when they did not want to.

To obtain rich data, the author stayed open during data collection to allow for new ideas to emerge through the interviews to expand the participants' narrative. Thus, the author orchestrated a myriad of skills, such as building rapport with participants via e-mail communication during and after data collection, being an authentic, non-judgemental, and active listener, emphasizing confidentiality and anonymity during data collection. Although the author was prepared for some unforeseen events, she did not experience technical difficulties, changes in the participants' availability for long interviews or changes in her motivation while doing online fieldwork.

Trustworthiness of the research was ensured through theory triangulation (Patton, 2015), i.e. Bourdieu's (1986) and Bronfenbrenner's (1979) theories 
and perspectives of the digital divide were collected and reviewed to better understand the link between parental social and cultural capital, the digital divide, and support to children in carrying out home-learning during the pandemic. Semi-structured, open interviews were a major source of primary data, allowing for an in-depth understanding of the families' decision-making process in their children's home learning experiences. The interviews helped obtain relevant background information from the participants with respect to their social realities. To enhance validity of the study, participants were asked to review interview transcripts and drafts of this manuscript.

\section{Data analysis}

Interviews were analysed between January and May 2021. Prior to the interview data analysis, the reviewed literature and theoretical frameworks were coded to compare the findings to the previous research at the end of data analysis. Then additional codes were added for the research question and each interview question to link the relevant literature to the coded interview data. Microsoft Excel was used to separate the data with initial codes from the literature (families' SES and educational background, learners' self-regulation skills, digital divide, i.e. lack of access to technologies, parental involvement, parental pedagogical challenges, school-level differences, communication with teachers) to later search for themes in the interviewees' data. The themes identified by the theoretical framework informed the direct quotes from participants (Hsieh \& Shannon, 2005). The next section reports on the results of the study.

\section{Results}

Families' experiences with student learning at home remotely

This subsection addresses families' experiences with student remote learning from March 2020 to May 2021. In response to the research question, the following themes emerged: "Family as an educational provider", "Family as a learner" and "Nothing has changed".

Family as an educational provider

Before ERE, the participants from our sample did not have to use technological devices such as computers, laptops, or smartphones to facilitate learning at home. Among six families participating in the interviews, only one reported that they had used Skype before March 2020 for online English lessons for one of their children. Another family said that they had been avoiding buying a smartphone for their primary school child because of 
health reasons. However, during remote learning at home, all participating families mostly used laptops and smartphones to access online lessons from home. Two families used TV broadcast lessons during April-May 2020 to access the lessons delivered by teachers of different subjects in two languages (Kazakh and Russian). Four participating families out of six in the study had to buy smartphones and laptops. In addition, families had to provide a designated space for learning in their homes, including a set of chairs and tables that were set up in accordance with the children's height. Two families did not have specific challenges regarding access to the Internet or technology. Additionally, they did not have to organize their space purposefully for ERE as their children had their separate rooms equipped with personal laptops, a set of earphones, and a reading corner (Families 1 and 2, Hungary).

Five families stated that ERE in both Kazakhstan and Hungary was unstructured in the beginning. It was time- and energy-consuming, chaotic, lacking social interaction with teachers and peers, pedagogical guidance and subject-content support from teachers and clarity in daily schedules, as well as overwhelmed by the amount of schoolwork and home assignments. Most families except for one reported that their child(ren) had to spend over ten hours studying in front of the computer and the TV. Specifically, at the beginning of ERE, students from lower SES, with lower ability to use technological devices and lower teachers' or parents' support, were less likely to return completed home assignments on time.

We weren't familiar with many online platforms for studying before. You see, there are a lot of applications or platforms, how do you join, where do you click to 'Enter', how and where do you register? We didn't know a lot of things. It was all new for us, that's why we had zero knowledge about these things. (Family 2, Kazakhstan, 2021, 23 ${ }^{\text {rd }}$ January)

Such family views surfaced mainly regarding ERE between April-May 2020 and in September 2020. A common view amongst four families was that ERE demanded both time and professional knowledge from parents at the beginning. Beyond providing access and the ability to use technology to connect to online lessons, some parents perceived remote learning at home as inconvenient, challenging and costly since they had to hire private subject tutors for one or more of their children. The need to hire a tutor mainly stemmed from the parents' lack of pedagogical and content knowledge, effect on parents' work and children's dependency on parents to keep them company at home.

... in the beginning it was mostly the parents... had to become teachers... it was really difficult because we are not teachers and we learned these things, for example, geometry... 30 years ago and I didn't use it, and it was difficult. I think most of the parents had to learn again this grade five, grade six. (Family 3, Hungary, 2021, $2^{\text {nd }}$ May) 
More than half of the participants recalled that their child(ren) needed greater parental involvement in the first months of ERE. These families' children had either just turned 11 or 12 or they had not experienced online education before nor owned a laptop. Parents had to sit by their child(ren) during the live lessons, remind them every day to send home assignments by e-mail, submit homework in specific LMS or send a screenshot as a WhatsApp message to the class chat (Family 1, 2, and 3, Kazakhstan; Family 3 , Hungary). To the contrary, families with children in middle and secondary school stated that they had not interfered with or controlled their children's class participation, class and home assignments, as well as that they had not assisted in technical support to connect to live lessons or communicate with teachers every week (Family 1 and 2, Hungary).

Family as a learner

Half of the families in this study described how learning, as seen traditionally in the school context, expanded and occupied the home space. Specifically, parents perceived learning to happen in school between the teacher and students. Parents were involved indirectly in children's learning, for example, by checking their homework, asking about school days and attending parent-teacher meetings. However, online education encouraged families to reconsider their parenting styles, expand their trust resulting in increased child(ren)'s learning autonomy and put more focus on their social interactions at home. For example, Family 2 from Kazakhstan initially felt puzzled by the online education concept and methods of teaching and learning. The mother emphasized that her digital skills and beliefs about online education did not let her be open-minded about online education. Thus, she projected the beliefs on her son. However, as there was no access to school and she invested time and effort into assisting her son in ERE, she realized she could learn about online education.

...apparently, it is possible to understand online education, you just need motivation and desire, and you learn sitting next to your child. I have learnt a lot. (Family 2, Kazakhstan, 2021, $2^{\text {nd }}$ May)

The entire family learnt to increase their trust in their son in managing online education. As a result, they witnessed the gradual growth of learner autonomy in their son.

Another family had to learn to trust their children because of their exhaustion with ERE conditions. Family 3 from Kazakhstan described that during April-May 2020 the whole family was suffering from enormous mental load related to online education. Learning from home seemed drastic, children did not know how to upload homework to LMS, and often it was the mother who had to help the children in online education from the morning until late 
evening. As a result, she said, she was yelling at children and crying but did not want to give up the situation. The mother also acknowledged it was a hard time for her husband, who suffered watching children and his wife cry every day and stay up late to finish homework. The husband did not get involved with helping children or the wife and took care of himself during ERE:

Right now, it is easier and maybe because I started to give up as well. I don't pay much attention to what my kids are doing right now and I don't check their homework anymore. I only ask if they finished homework, and then I say, okay, good job... Now children try to manage their time by themselves, they developed awareness, and I don't control them anymore. (Family 3, Kazakhstan, 2021, 30 $0^{\text {th }}$ January)

Interestingly, the family with a high-school student learnt how schoolteachers were trying to bring authentic education while children learnt from home. She said, "...this morning, he shared with me...his math teacher explained the thinking behind the math that they were studying... they had a lengthy discussion about whether you can divide the number zero or not..." (Family 1, Hungary)

To answer the research question, the author explored multifaceted families' experiences with student learning at home remotely, showing differences between parents' Internet access, children's age level, parents' pedagogical and subject knowledge and increased trust towards online education. The analysis also revealed that families had to respond to many children's needs and emotions at the beginning of remote learning in 2020.

\section{Nothing has changed}

The issues related to the other five families' experiences with ERE and captured in the previous three themes were not related to Family 2, Hungary. However, it was noteworthy to code and include this family's response as well. The family consists of two parents and two children, a toddler and a middle-school student, living in their own house in the capital city. The mother works from home while the father's management role at his working place demanded him to be in the office every day during the pandemic. The author inferred that this family's life did not change drastically compared to other family participants.

Although the father did not recall changes in the involvement with the son's online learning ("I had the same life in the last year that I used to have before"), he talked at length about the challenges regarding the organization and delivery of ERE by teachers. In the interview, the father mainly referred to the challenges in teachers' inability to transition from the traditional classroom pedagogy to the online teaching format. Overall, the father did not think that ERE brought about significant changes in his son's learning, nor 
that organizing and providing appropriate conditions for his son's learning was financially difficult. His son, who was in middle-school, owned a laptop and other necessary technological devices for learning before the pandemic.

In responding to the question, "How did your role change as the parent with the pandemic in relation to your child's learning?", "for eight years, he had a 4.8-4.5 grade point average. He didn't have any problems with learning... And I don't have to ask him, is it really a five or four [grade]?" (Family 2, Hungary, 2021, 28 ${ }^{\text {th }}$ April)

The next section features a discussion on the way in which the results of the study relate to the reviewed literature and supplement the findings of previous research on parental involvement in children's remote learning.

\section{Discussion}

The aim of this study was to promote our understanding of the roles of families in their children's remote learning experiences. Based on the interviews with six families from Kazakhstan and Hungary, families' experiences in student learning at home remotely were analysed.

According to the analysis, ERE revealed inadequate preparedness of schools and teachers in terms of technological and pedagogical skills, explained increasing gaps in educational inequalities in the digital era and offered solutions for post-COVID-19 schooling. Families' experiences presented in this study confirmed the consequences of the extraordinary ripple effect of COVID-19.

The results indicate that insufficient provision and delivery of poor-quality online content for students, the limited financial abilities and proficiency of families in subject knowledge and pedagogy, as well as the limited abilities of families for using and integrating technologies for learning at home, increased stress on families and affected student learning. Results of this study corroborate the findings of the existing literature (van Dijk, 2005; van Deursen \& van Dijk, 2011; Scheerder et al., 2017; Hermann, 2020; KendeMessing, 2020; Bokayev et al., 2021; Kovyazina et al., 2021).

First, consistent with prior research, families with higher income, higher educational levels and complete families (i.e. with two parents) were more likely to possess digital devices and the Internet connection (DiMaggio \& Hargittai, 2001; van Dijk, 2005). The discrepancies in accessing the Internetenabled devices had existed before the pandemic. With the pandemic, the digital divide expanded, affecting the disadvantaged groups of children (Cullinane \& Montacute (2020). The results validate Bordieu's (1986) theory linking families' social and cultural capital to digital and educational inequalities. Students who attended private schools in Kazakhstan and Hungary, having their own rooms and infrastructure for learning at home, 
were less likely to experience challenges in remote learning. Their teachers interacted with students more by responding to their learning needs and emotions (Radó, 2021), as opposed to the teachers from public schools, who struggled with providing and delivering high-quality online content for their students (Kovyazina et al., 2020).

A possible explanation of the differences in schools provision of remote online education is that schools and governments in both countries were not ready for ERE and lockdown (Bokayev et al., 2021; Csapó \& Molnár, 2019). Most state school teachers felt forced to use the national LMS that did not create and deliver authentic remote online education to both teachers, families and students (ibid). As a result, this limitation of user-friendly national LMS affected student progress and assessment. In turn, it concerned most of the parents in our sample of participants. There are similarities between the families' views expressed in Dong et al. (2020), Garbe et al. (2020) and Greenhow et al. (2021). These studies, conducted during the pandemic, suggest that interaction is crucial in remote online learning and that a high level of engagement is essential. Interaction can happen in both synchronous and asynchronous online learning through live streaming videoconference lessons in breakout rooms for group work, teachers polling students to give immediate feedback in real-time, adding online applications for quiz, and more (Greenhow et al., 2021).

Secondly, significant qualitative changes in the division of labour took place with the increasing parental involvement in ERE. It presented families with different types of challenges. For example, most participants from the study struggled to assist their children in professional pedagogical and subject knowledge and instructional support. Some higher educated, middle-class families struggled to balance work and their child(ren)'s learning at home in semi-private or fully private schools. Others were freelancing from home and providing emotional support to children in navigating learning at home. Therefore, these families chose to hire a few private tutors for one or two of their children.

On the other hand, the families who could not afford a private tutor had to either search for lesson explanations on YouTube or ask for teachers' feedback at local LMS. This strategy shows that lower-educated workingclass families could have faced more challenges in finding time for children and larger financial worries or had less time for themselves. This result aligns with the findings of Ullah and Ali (2018), indicating that parents whose children attended private schools were more actively involved with their children's learning and provided private tutors. It has been shown in the European countries that families of lower SES are less likely to provide a quiet room to study and the support during school closures (European Commission, 2020). 
These findings are rather disappointing, as they signal that most education systems, including Kazakhstan and Hungary, are not ready for the digital world and online learning opportunities. The findings illustrate growing inequalities in accessing quality education for students of diverse backgrounds. Specifically, families and students from the poorest backgrounds experienced learning losses and limited social mobility.

The results of this study show that families who had previous experience in using Web applications for their work or for providing online learning to their children prior to COVID-19 were more positive about remote online education. Specifically, their beliefs about integrating Web applications into children's remote online education provided their children with richer learning experiences. For example, participants from both countries reported that transferring responsibility for learning to children had affected them positively. Specifically, they saw how the children could self-regulate themselves, create and follow a daily routine in remote online learning conditions and manage their learning. This result supports other studies in this area, linking student participation as an unexpected advantage of learning at home remotely (Reimers \& Schleicher, 2020; Scheerder et al., 2017; van Deursen \& van Dijk, 2011). However, research prior to COVID-19 suggests that children need guidance from teachers, motivation and self-management skills to study online remotely (Lewin et al., 2018, p.50). Further research needs to closely examine self-motivation and self-management in remote online learning concerning the aspects of students' SES, family's educational background, types of schools and age.

Three families from Kazakhstan that participated in the study reflected on increased trust in remote education. It is an important finding that needs to be further researched in order to understand parents' views. None of the families in Hungary, on the contrary, mentioned whether their attitudes had changed due to schooling during the pandemic being remote.

The Bronfenbrenner's (1989) theory illustrates how the COVID-19 pandemic introduced massive changes in the lives of families with school children. The impact of the pandemic is reflected in the fact that the affected families had to be involved with their children's learning more closely and invest into technology devices to access remote learning. As Bond (2020) asserts, close parental involvement was evident in more than $50 \%$ of the reviewed 89 studies on teaching and learning during the COVID-19 pandemic (p. 206). However, as Popyk (2020) highlights, many families could not provide or fix technology devices to support student learning at home remotely. In this line of research, the study of Race (2020) is noteworthy since it discusses how poor Internet connectivity and lack of Internet quota limited students in accessing education remotely. On the other hand, Bubb and Jones (2020) report on how some students thrived in remote learning during the pandemic because they could own the pace of their learning. 
The final result shed light on the participant family that did not experience large changes, challenges or learning points related to ERE. The reasons for this family's experiences in adapting to ERE included the male parent's ability to balance his job and establish ground rules with the child on his selfmanagement and self-regulation from the primary school years. The student's academic progress, access to technology and the ability to use it did not change at large compared to the pre-COVID times. The family's priorities can explain this finding in the child's learning beyond his academic achievement, the support from other family members working at home with flexible work schedules and middle-class family's SES. Family 3 from Hungary was the most distinctive since the pandemic and learning at home remotely had not impacted their son's learning in comparison to other participants from both Hungary and Kazakhstan.

\section{Conclusion}

The findings support the emerging trend in educational research that COVID-19 mediates the changing nature of traditional school education to remote online education. The paper outlined the ways in which Kazakhstani and Hungarian families contributed to their children's learning at home remotely not only by purchasing new devices for remote learning but also by substituting teachers for their children, upskilling the parents' digital literacy and increasing parental engagement on the whole. However, disadvantaged children and families found themselves unable to enjoy learning during ERE. This happened because educational policies directed at upgrading digitalization of education, including the development of school ICT infrastructure, teachers' professional development of ICT skills, as well as training and supporting families on scaffolding learning for their children in ERE, were not in place. This study contributes to the discussion and literature on the digital divide and social and cultural capital (Bourdieu, 1986) of educational inequalities in Kazakhstan and Hungary. We found that the digital divide existed in these countries and related to the families with low SES and educational background, schools attended by children and the ability to use Web applications.

Digital skills are essential for the technological era. Existing inequalities in accessing technology and developing skills could further intensify social and cultural capital gaps as school children transition to higher education and the job market. The study contributes to the literature on the developmental ecology framework in parental involvement in Kazakhstan and Hungary. By employing the framework as an analytical approach, it is possible to understand larger influences of multiple systems within the social context of these families' challenges in the transition to ERE in Kazakhstan and Hungary. Some actions could neutralise the negative influences of the disadvantaged 
families within students' ecosystems. For instance, we need to review digital education policies, to train school teaching staff on ICT skills, to upgrade schools regarding ICT infrastructure, to equip the disadvantaged families with ICT devices and to build collaboration between schools, families, students and communities. What we have learnt from this study is that all children need support during remote online learning. However, the disadvantaged children and families had less access to continue education from home remotely because of the existing social and educational inequalities in their societies.

\section{Limitations of the study}

Initial recruitment of the participants progressed slowly, resulting in extended 'waiting time' to find the participants open to talk about their experiences related to the research question. The author anticipated that hiring Kazakh-speaking and Hungarian-speaking assistants could increase the chances of gaining access to Kazakh-speaking and Hungarian-speaking families from rural settings. However, due to travel restrictions and health measures during the global pandemic and remote locations of families residing in rural areas, it was not possible to include these participants in the study. Namely, participants' lack of stable Internet connection in villages, absence of experiences and perceptions of virtual interviews and access to high-quality technical device functionality to hold virtual interviews limited the author in recruiting participants of diverse backgrounds for the study.

As previously reported, participants' demographic data showed that they were predominantly female parents from middle-class and working-class SES. It would facilitate capturing more diverse views if participants represented different family roles, a variety of income levels and types of schools. The research aimed at participants who had organized home learning and been in lockdown for almost a year since the pandemic outbreak. Additional research needs to explore and understand the long-term effects of the pandemic on students' re-adjusting to traditional schooling conditions when it becomes safe to come back to brick-and-mortar schools. Furthermore, this research could add to understanding schools and parents as funds of knowledge in critical times.

The research could offer further insight into virtual synchronous data collection to consider risks and opportunities in methodological considerations in the research population and sample. Specifically, this refers to the issues of which decisions to take in gaining access to key participants and organizations, developing a procedure for involving colleagues to assist, guidance and solving unforeseen challenges during the fieldwork, including researcher's physical and mental capacity. 


\section{References}

Beckman, K., Bennett, S., \& Lockyer, L. (2019). Reproduction and transformation of students' technology practice: The tale of two distinctive secondary student cases. British Journal of Educational Technology, 50(6), 3315-3328. http://doi. org/10.1111/bjet.12736

Bokayev B., Torebekova Z., Davletbayeva Z., \& Zhakypova F. (2021). Distance learning in Kazakhstan: estimating parents' satisfaction of educational quality during the coronavirus, Technology, Pedagogy and Education, 30:1, 27-39.http:// doi.org/10.1080/1475939X.2020.1865192

Bond, M., Zawacki-Richter, O., \& Nichols, M. (2019). Revisiting five decades of educational technology research: A content and authorship analysis of the British Journal of Educational Technology. British Journal of Educational Technology, 50(1), 12-63. https://doi.org/10.1111/bjet.12730

Bourdieu, P. (1984). Distinction: A social critique of the judgment of taste. Harvard University Press.

Bourdieu, P. (1986). The forms of capital. In J. Richardson (Ed.), Handbook of theory and research for the sociology of education (pp.241-258). Greenwood Press.

Bourdieu, P. (1998). The forms of capital. In A.H. Halsey, H. Lauder, P. Brown, and A.S. Wells (Eds.), Education, culture, economy, society (pp. 47-56). Oxford University Press.

Bozkurt, A., \& Sharma, R. C. (2020). Emergency remote teaching in a time of global crisis due to Corona Virus pandemic. Asian Journal of Distance Education, 15(1). http://doi.org/10.5281/zenodo.3778083

Brooks-Gunn, J., Berlin, L. J., Leventhal, T., \& Fuligni, A. (2000) Depending on the Kindness of Strangers: Current National Data Initiatives and Developmental Research. Child Development,71(1), 257-268.http://doi.org/10.1111/14678624.00141

Bubb, S., \& Jones, M.-A. (2020). Learning from the COVID-19 home-schooling experience: Listening to pupils, parents/carers and teachers. Improving Schools, 23(3), 209-222. https://doi.org/10.1177/1365480220958797

Cho, J., \& Trent, A. (2006). Validity in qualitative research revisited. Qualitative Research, 6(3), 319-340. https://doi.org/10.1177/ 1468794106065006

Csapó, B., \& Molnár, G. (2019). Online diagnostic assessment in support of personalized teaching and learning: the eDia System. Frontiers in Psychology, 10, 1522. https://doi.org/10.3389/fpsyg. 2019.01522

Cullinane, C., \& Montacute, R. (2020). COVID-19 and social mobility impact brief \#1: school shutdown. Sutton Trust.

Dalayeva, T. (2013). The e-learning trends of higher education in Kazakhstan. Procedia - Social and Behavioral Sciences, 93, 1791-1794. http://doi.org/10.1016/j. sbspro.2013.10.118

DES (2016). Digital education strategy of Hungary. Digital success programme. http:// www.kormany.hu/download/0/4b/21000/The\%20Digital\%20Education\%20Strategy\%20of\%20Hungary.pdf 
Dickens, C., \& Dunn, H. (1921). A Tale of Two Cities. Cosmopolitan Book Corporation. Retrieved from the Library of Congress, https://www.loc.gov/item/22004431/

DiMaggio, P., \& Hargittai, E. (2001). From the 'digital divide' to 'digital inequality': Studying Internet use as penetration increases. Princeton: Center for Arts and Cultural Policy Studies, Woodrow Wilson School, Working papers 47, Princeton University, 4(1).

DiMaggio, P., Hargittai, E., Celeste, C., \& Shafer, S. (2004). Digital inequality: From unequal access to differentiated use. In K. Neckerman (Ed.), Social inequality (pp. 355-400). Russell Sage Foundation.

Dong, C., Cao, S., \& Li, H. (2020). Young children's online learning during COVID-19 pandemic: Chinese parents' beliefs and attitudes. Children and Youth Services Review, 118, 105440, 1-9. http://doi.org/10.1016/j.childyouth.2020.105440

European Commission. (2020). Educational inequalities in Europe and physical school closures during Covid-19. fairness policy brief series. The European Commission's science and knowledge service: Joint Research Centre.

Garbe A., Ogurlu U., Logan N., \& Cook, P. (2020). COVID-19 and Remote Learning: Experiences of Parents with Children during the Pandemic. American Journal of Qualitative Research, 4(3), 45-65. http://doi.org/10.29333/ajqr/8471

Greenhow C., Lewin C., \& Bret Staudt Willet, K. (2021). The educational response to Covid-19 across two countries: a critical examination of initial digital pedagogy adoption. Technology, Pedagogy and Education, 30(1), 7-25. http://doi: 10.1080/1475939X.2020.1866654

Hanushek, E. A., \& Woessmann L. (2006). Does educational tracking affect performance and inequality? Differences-in-differences evidence across countries. Economic Journal 116(510), C63-C76.

Hargittai, E. (2002, April). Second-level digital divide: Differences in people's online skills. Hargittai, E. (2003). How wide a Web? Inequalities in accessing information online [Unpublished doctoral dissertation]. Princeton University, Princeton, NJ.

Hasan, N., \& Bao, Y. (2020, November). Impact of 'e-Learning crack-up' perception on psychological distress among college students during COVID-19 pandemic: A mediating role of 'fear of academic year loss. Children and Youth Services Review, 118, 105355. http://doi.org/10.1016/j.childyouth.2020.105355

Hermann, Z. (2020, February 4). How many students do not reach online learning? Institute of Economics, Research Center for Economics and Regional Studies. https://www.mtakti.hu/koronavirus/hany-diakhoz-nem-jut-el- az-online-tavoktatas/12769/

Hohlfeld, T. N., Ritzhaupt, A. D., \& Barron, A. E. (2010). Connecting schools, community, and family with ICT: Four-year trends related to school level and SES of public schools in Florida. Computers \& Education, 55, 391-405. http:// doi.org/10.1016/j.compedu.2010.02.004

Hollingworth, S., Mansaray, A., Allen, K., \& Rose, A. (2011). Parents' perspectives on technology and children's learning in the home: Social class and the role of the habitus. Journal of Computer Assisted Learning, 27, 347-360. http://doi. org/10.1111/j.1365- 2729.2011.00431.x 
Hsieh, H-F., \& Shannon, S.E. (2005). Three approaches to qualitative content analysis. Qualitative Health Research, 15(9), 1277-1288. DOI:10.1177/1049732305276687

Ibrayeva, A., Kassymzhanova, A., Otynshiyeva, A., Yergali, A., \& Seifullina, A. (2018). Elearning in Al-Farabi Kazakh National University (KazNU): experience, problems, development prospects. Europena Conference on e-Learning, XVIII, 185-193.

Information and Analytical Center. (2020). National collection 'Statistics education system of the Republic Kazakhstan'. Nur-Sultan.

International Monetary Fund. (2021). World Economic Outlook: Managing Divergent Recoveries. Washington, DC, April.

Kende, A., \& Messing, V. (2020, May 12). Így tűnnek el a magyar közoktatásból a hátrányos helyzetü és roma gyerekek a járvány idején [How disadvantaged and Roma children disappear from the Hungarian public education at the time of pandemic]. https://qubit.hu/2020/05/12/igy-tunnek-el-a-magyar-kozoktatasbola-hatranyoshelyzetu-es-roma-gyerekek-a-jarvany-idejen

Kovyazina, K., Boranbai, M., \& Beisembayev, S. (2020). Дистанционное образование в Казахстане глазами учителей и экспертов: Вызовы и Возможности [Distance education through teachers' and experts' lens: Challenges and Opportunities]. Paper Lab.

Lewin, C., Whitton, N., Cummings, J., Roberts, B., Saxon, D., Somekh, B., \& Lockwood, B. (2008). MILO: Models of innovative learning online at KS3 and 14-19 Final Report. Becta. https://dera.ioe.ac.uk/1464/1/becta_2008_modelsinlearningonline_report.pdf

Liu, F., \& Cavanaugh, C. (2011). Success in online high school biology: Factors influencing student academic performance. The Quarterly Review of Distance Education, 12(1), 37-54, 71-72

Ministry of Education and Science of the Republic of Kazakhstan. (2021). General information. Retrieved from https:/www.gov.kz/memleket/entities/edu/ about?lang=en

Mossberger, K., Tolbert, C. J., \& Stansbury, M. (2003). Virtual inequality: Beyond the digital divide. Georgetown University Press.

Nurmukhametov, N., Temirova, A., \& Bekzhanova, T. (2015). The problems of development of distance education in Kazakhstan. Procedia - Social and Behavioral Sciences, 182, 15-19.

OECD (2019). TALIS 2018 Results (Volume I): Teachers and school leaders as lifelong learners. OECD Publishing, Paris. https://doi.org/10.1787/1d0bc92a-en

Patton, M. Q. (2015). Qualitative research and evaluation methods (4th ed.). Sage.

Popyk, A. (2020). The impact of distance learning on the social practices of schoolchildren during the COVID-19 pandemic: reconstructing values of migrant children in Poland. European Societies, 1-15. https://doi.org/10.1080/14616696 .2020 .1831038

Povey, J., Campbell, A. K., Willis, L.-D., Haynes, M., Western, M., Bennett, S., Antrobus, E., \& Pedde, C. (2016). Engaging parents in schools and building parent-school partnerships: The role of school and parent organization leadership. International Journal of Educational Research, 79, 128-141. http://doi. org/10.1016/j. Ijer.2016.07.005 
Putney, N. M., \& Bengston, V. L. (2002). Socialization and the family revisited. In R. A. Settersten \& T. J. Owens (Eds.), New frontiers in socialization (pp. 165-194). Elsevier. https://doi.org/10.1016/S1040-2608(02)80034-X

Race, R. (2020). Emergency response online classes during community quarantine: An exploratory research to Philippine private schools. Universal Journal of Educational Research, 8(8), 3502- 3508. https://doi.org/10.13189/ujer.2020.080825

Radó, P. (2021). The institutional conditions of adapting to future challenges in the hungarian education system. working paper. Open society foundations. Central European University.

Reimers, F., \& Schleicher, A. (2020). Schooling disrupted, schooling rethought. How the Covid-19 pandemic is changing education. OECD. https://globaled.gse.harvard. edu/files/geii/files/education_continuity_v3.pdf

Sapargaliyev, D. (2012). E-learning in Kazakhstan: stages of formation and prospects for development. International Journal of Advanced Corporate Learning,(iJAC), 5(4), 42-45. Kassel University Press GmbH. Retrieved November 25, 2021 from https://www.learntechlib.org/p/45633/

Scheerder, A., van Deursen, A., \& van Dijk, J. (2017). Determinants of Internet skills, uses and outcomes. A systematic review of the second-and third-level digital divide. Telematics and Informatics, 34(8), 1607-1624.

Szaszin, E. (2020, May 12). Students have done well in digital transition-research on living distance learning experience. Márkamonitor. https://markamonitor. hu/2020/05/12/digitalis-atallasbol-jol-vizsgaztak-a-diakok-kutatas-a-tavoktatasmegeleserol//digitalis-atallasbol-jol-vizsgaztak-a-diakok-kutatas-a-tavoktatasmegeleserol/

Ullah, H., \& Ali, J. (2018). Schools and families: reproduction of class hierarchies through education in Pakistan. Pakistan Journal of Criminology, 10(3), 86-105.

UNESCO. (2020). UNESCO's support: Educational response to COVID-19. UNESCO. https://en.unesco.org/covid19/educationresponse\#schoolclosures

Van Deursen, A., \& Van Dijk, J. (2011). Digital skills and the digital divide. New Media and Society, 13(6), 893-911. http://doi:10.1177/1461444810386774

van Dijk, J. A. G. M. (2005). The deepening divide. Sage.

Vygotsky, L. S. (1978). Mind in society. M. Cole, V. John-Steiner, S. Scribner, \& E. Souberman (Eds.) Mind in Society the Development of Higher Psychological Processes. Harvard University Press.

Официальный Сайт Президента Республики Казахстан (2020, 15 марта). О введении чрезвычайного положения в Республике Казахстан [State of emergency in the Republic of Kazakhstan]. Retrieved from: https://www.akorda.kz/ ru/legal_acts/decrees/o-vvedenii-chrezvychainogo-polozheniya-v-respublikekazahstan

Официальный информационный ресурс Премьер-Министра Республики Казахстан [Official information source of the Prime Minister of the Republic of Kazakhstan] (2020, 17 апреля). Retrieved from: https://www.primeminister.kz/ru/news/vse-shkoly-rabotayut-v-normalnom-rezhime-mon-rk-ob-itogah-vtoroy-nedeli-distancionnogo-obucheniya-1734621 


\title{
Uloga porodice $u$ dečjim iskustvima učenja na daljinu tokom pandemije COVID-19: Kazahstan i Mađarska
}

\author{
Assel, Csonka-Stambekova ${ }^{5}$
}

Odeljenje za obrazovanje nastavnika, Univerzitet Eötvös Loránd

Pandemija COVID-19 primorala je škole širom sveta da se zatvore. Usled toga, porodični dom postao je dominantno okruženje za učenje, a članovi porodice postali su osobe koje treba da obrazuju učenike. Dosadašnja istraživanja pokazuju da su porodice različito reagovale na nove uloge i izazove u vezi sa učenjem na daljinu. Pored toga, istraživanja iz početnih faza pandemije COVID-19 ukazuju da su socio-ekonomski status i nivo obrazovanja članova porodice povezani sa dečijim iskustvima učenja na daljinu. Ovo istraživanje teži da unapredi naše razumevanje učenja na daljinu u ranoj fazi pandemije kroz analizu iskustava tri kazahstanske i tri mađarske porodice. Porodice koje su učestvovale $u$ istraživanju se razlikuju po socio-ekonomskim karakteristikama, uključujući jezik koji govore, tip naselja u kom žive, nivo obrazovanja i status zanimanja članova porodice. Podaci prikupljeni kroz polustrukturirane onlajn intervjue sa roditeljima analizirani su kvalitativnom analizom sadržaja. Rezultati istraživanja pokazuju sledeće: a) roditelji su, pored svoje primarne uloge staratelja, preuzeli ulogu nastavnika; b) prilike za učenje kod kuće tokom pandemije COVID-19, kao i rizici, povezani su sa socioekonomskim statusom porodice; v) pojedinim porodicama bilo je teško da podrže svoju decu usled nedostatka pedagoških znanja i znanja predmetnih sadržaja. Može se zaključiti da postojeće društvene i obrazovne nejednakosti u Kazahstanu i Mađarskoj mogu imati dugotrajne negativne efekte na decu iz porodica koje se nalaze u nepovoljnjijem socio-emocionalnom položaju.

Ključne reči: učenje na daljinu u situaciji krize, izbijanje pandemije COVID-19, roditelji, učenje od kuće

5 Assel, Csonka-Stambekova, https://orcid.org/0000-0001-5101-2640

This study has received no funding.

Correspondence to: Assel Csonka-Stambekova, Teacher Education Department, Eötvös

Loránd University

Contact: assel.stambekova@ppk.elte.hu 